\title{
I-Witnessing; Reflections on Cosmopolitanism in Kigali
}

\author{
Hilary Yerbury \\ University of Technology, Sydney
}

\begin{abstract}
Starting from the classic view of cosmopolitanism, this paper uses personal experiences gained during a fiveweek stay in Rwanda with a family affected by the genocide to explore the disjuncts which emerge in trying to understand the concept. In this process of exploration, it considers conceptions of the guest, the stranger and what Geertz terms the 'cosmopolite'. Taking a reflexive position, it explores what it means to be a witness to events in someone else's life, with a focus on post-genocide reconciliation that took place in the family in January and February 2011. In this context, it introduces the notions of cosmopolitan curiosity (Appiah) and cosmopolitan tolerance (Beck) and finds each of them affected by structural imbalances which render them potentially inadequate in practice. The paper concludes that, from a reflexive point of view, an understanding of cosmopolitanism is a work in progress, and that it is much more difficult to sustain as a lived reality than it is as an abstraction.
\end{abstract}

\section{Reading this paper}

The reader can approach this paper in one of two ways. Whichever approach the reader adopts, the purpose of the paper is to explore theoretical and conceptual dimensions of cosmopolitanism through the author's experiences in Rwanda. The reader can begin below with the section entitled Prologue, sharing something of the author's experiences over a period of several weeks with a family in Rwanda and then return to read the Introduction and continue with the reflections on these experiences through the lens of cosmopolitanism; this reading conveys something of the tentative and personal nature of the reflections. Or, the reader can continue here for a more structured reading. In this reading, the reader is introduced to Louise, the Rwandan woman whose wish for a witness to her personal reconciliation led to reflections on cosmopolitanism; and to the author who acted as this witness. The reader can know in advance that the Prologue contains extracts from the author's travel diary during a six-week stay in Rwanda, and that these tell the story of the separate strands of her relationship with a Rwandan woman of the same age, who had suffered during the genocide and had sought personal reconciliation which occurred during that stay; and who was active in civil society and had worked in building the post-colonial and post-genocide nation. The reader can then take a more removed approach to the exploration of the concept of cosmopolitanism. 


\section{Introduction}

Early in January 2011, I arrived in Kigali, the capital of Rwanda. I was there to spend five weeks as a volunteer at the Kigali Institute of Education's Centre for Gender, Culture and Development and to carry out interviews with young activists to further my current research. I was to stay with a family. This accommodation had been arranged for me at third-hand by a young Rwandan woman studying in Canberra, a friend of a friend, who knew that the parents of one of her closest friends in Kigali would be very happy to take in a visiting foreigner for a month or so. From a few emails and a telephone conversation before I left Sydney, I learned that there were five daughters in the family, the oldest of whom had studied in South Africa and the younger ones who would want to practice their English, that the father was a doctor, that the parents were Francophone and that the house was close to KIE. I imagined that I would use my ability to speak French to help bridge the cultural gaps between us and that my experience of living with a family in neighbouring Burundi for three weeks the previous year had given me some insights into social relations. I had remarked to friends in Sydney that it felt a little like going to stay with a pen-friend as a teenager.

In that frame of mind, I arrived in the family intending to be a good guest, fitting in with family routines, speaking English with the younger daughters, describing life in Australia in answer to questions and open to learning about daily life for an educated middle class family in Kigali. My intentions did not exactly match those of Louise, the mother of the family, a woman two years younger than me. On my first Sunday with the family, on the fourth day after I had arrived, she asked me to promise her that I would do something. I had already made promises as a good guest - not to get up early but to stay in bed until an agreed time (when the hot water for washing would be brought) and to eat two thick slices of bread for breakfast instead of one - and so I agreed. I was caught off guard when she asked me to take on a responsibility - to be the witness for her and her family when I returned to Sydney.

\section{Introducing myself}

I am a woman in my early sixties, and for many years I have been an academic in Australia, mostly in Sydney. I grew up in small rural town in southwest England where my father's family have lived for generations, working as dyers for the woollen mill and as gardeners. I was one of only two in the large extended family to finish high school and the only one to go to university. I chose my undergraduate degree, a joint honours degree in French and Spanish, because its purpose was to train us to 'become' French (and Spanish), so that we could 'pass', linguistically and culturally. As a young woman, I was very proud of the fact that I could easily be taken for an educated French woman. Since my student days in France and Spain in the 1960s, I have been a passionate advocate of democratic processes. When I came to Sydney in the mid- 
1970s, my skills and experiences were not valued and, like many migrants, I re-invented myself, first as a public librarian with a concern for freedom of access to information and then as an academic in the emerging field of information studies, developing a professional agenda that switched the focus from the organisation of documents to identifying the needs and expectations of ordinary people for the information that would help them make decisions in their lives and be active members of civil society.

\section{Introducing Louise}

Louise is a woman in her early sixties. Her family came from the south-western part of Rwanda, a wealthy agricultural area and an area important in Rwandan history in the $20^{\text {th }}$ century and rich in tradition, both local and colonial. She married her childhood sweetheart, a young man from a family with longstanding links with her family. She is Tutsi and he is Hutu. They are both devout Catholics. They were both well educated; he was trained as a doctor. After the birth of their first child, they moved to Kigali where he took up a post in the major hospital and they spent several years overseas, both in Belgium and in other countries in West Africa. They have five daughters, the youngest being eighteen. Their fourth daughter is an orphan whom they adopted after the genocide of 1994. When they moved to Kigali from the south-west, they bought land on the outskirts of the city as it then was and built a large and comfortable family home in what would become a solid middle-class suburb. They value education and have ensured that all of their daughters have a university education.

Their families were actively involved in the development of the post-colonial nation, from the 1970s. One of Louise's brothers was an exiled member of the Rwandan Patriotic Front in the late 1980s and early 1990s, the party which brought the current president, Paul Kagame, to power. Another of her brothers was Mayor of a significant community in the late 1990s and early years of the $21^{\text {st }}$ century. Most members of Louise's family were killed during the genocide of 1994; her brothers survived because they were both living out of the country. Louise herself was active in politics and in civil society. She came to the end of her term as a locally elected representative in February 2011. She works with a collective of genocide widows, providing them with fruit and vegetables from lands that she owns to sell at the nearby market. She had been a member of the National Women's Council, and was celebrated for that contribution at a ceremony which was televised. She made the decision to withdraw from local politics and not to stand for re-election only on the day of the election, 4 February 2011. 
The life to which Louise asked me to be a witness was woven together from these two strands, the strand of the events of the genocide, which she referred to commonly as "les perturbations”, and the strand of the re-building a Rwandan society through political engagement, both of which led to reconciliation, one at the personal level and the other at the national level. This process of witnessing is not an objective, external, process; "I" am part of it too. I have created the narrative below in the Prologue from my diary notes. The narrative on the events of the genocide and reconciliation is on the left and the narrative on political engagement and reconciliation is on the right. I have used these notes and the experiences on which they were based to explore the concepts of the guest and the stranger, cosmopolitanism and reconciliation.

\section{Prologue \\ Extracts from a travel diary}

Extract 8 January 2011

I had a long talk with Louise. She is involved in local politics, in the National Women's Council, trying to persuade local women to become actively involved in politics. Local elections will be held next month, so this is a busy time for her, with many meetings. She is passionate about the need to support inclusive change and to do it with solidarity. I see traces of the kind of solidarity that means living by the rules.

Extract 8 January 2011

"Ma mère est morte [my mother died]. She was about your age when she died.

She shouldn't have died."

Extract 11 January 2011

"When we came back in 1995, the house was destroyed. We wanted to live here. We fixed it all ourselves."

“W. - you know W., don't you? - he and his family used to live opposite - we were in Liège together. They didn’t come back here after the genocide. No, don't say anything to him.”

Extract 13 January 2011

I realize that in writing this entry, I've been skirting around the most significant thing. Louise gave her testimony. It's easy to write the words. It did catch me off guard. I already knew that the family had been affected by the troubles and that they'd been displaced. But Louise described in detail how she had been targeted by one of her neighbours And how another neighbour had stepped in to give them a safe place to be while they arranged to flee elsewhere. The second time she went through the story, it was a kind of re-enactment. "I was here, this is what I heard, this is what I saw, this is what happened, this is what we did." 
"We heard them in the street. We knew they would come in. Jean-Marie and the older girls were sitting here. I took the baby and went to hide at the end of the house. Jean-Marie said they should kill him first and he began to pray aloud. One of our neighbours came. One of them had a machete, he was standing there. There was another one here by this little wall. Others were outside. Our neighbour said they should leave us alone and he would make sure they did. They said I was on the list. The neighbour said they should know me and they should leave. The baby was crying so I came out. I stood here. The neighbour said he would make sure we were safe and could leave.”

"My brothers and sisters - everyone - they were all killed. My mother was there too. All the bodies fell on top of her so she was saved. She waited and waited and when it was dark she went back up to the hill. She stayed there three weeks by herself. She didn't go outside. She felt safe because everyone thought she was dead. Eventually she went down the hill to Jean-Marie's family. She thought they would look after her. The families have always known each other. Someone must have said something. They came for her. Jean-Marie's family didn't protect her. They could have but they didn't. The genocidaires humiliated her. They [descriptions of atrocities] and made her watch. Then they [descriptions of violence] and took her legs and threw her body in the well. I went to the gacaca, that's how I found out. I needed to know what happened."

Extract 14 January 2011

“Tomorrow, Jean-Marie's family are coming. We will eat together and then we have to talk. No, you don't have to go out. I want you to meet them. I don't know what we will be doing. Maybe we will be laughing and joking and maybe we won't. I don't know.”

Extract 15 January 2011

"Mwiriwe [Hello, good afternoon], how was your class? Come, let me introduce you to Jean-Marie’s family. They all speak good French. ... Now, I think you should go inside with the girls."

The girls and I chat about inconsequentials. Suddenly we hear a wail, a piercing lamentation. I've never heard anything like it. It seemed to get right inside me. We see Louise get up from the verandah and go towards the garden, continuing to wail. The girls tell me what I should probably have worked out - that Jean-Marie's family have come to be reconciled with Louise. This is the first time in sixteen years that they have been to the house. I feel awkward. This is not something I should see or hear or know about. I go to my room and close the door. I lie on the bed, trying not to be there, but at the same time, listening. From the sound of voices, I assume that Louise has come back to her seat. They are speaking Kinyarwanda, so I cannot understand what they say. An old man's voice begins to speak. He speaks for some time. He must be telling a story, from the way his voice rises and falls. And now he is praying. The tone of the voice has changed and I hear God called upon many times, one of the words I know - Imana. The praying continues, occasionally with responses. A final amen and a long silence. No one moves, the chairs don't scrape on the tiles. Then a woman's voice begins to sing: Amahoro, peace, (another of the words I know); this is a song or hymn I have heard elsewhere. The singing continues, hymns and songs with everyone joining in - and with the sound of fidgeting and movement that suggest the tension has been broken. Some time later, there is a tap on my door and one of the older girls comes to see if I am OK. She tells me the 
families are reconciled. I try to explain that this has been far beyond anything I can comprehend. Then Louise comes. She says: "Well, that's it, it's over.

Now we can think about the future.” I try to apologise, saying that I have felt in the way, "de trop", in something which was highly significant for her family. She says she heard that I was frightened by the events and that's why I went to my room. There was no need for me to do that and she was sorry I was upset. She explains that all she ever wanted was for Jean-Marie's family to recognize what happened to her mother and to acknowledge that they might have done something; and now she has that.

Extract 16 January 2011

I can't/don't feel I should write the details. ... I know about state-based and structural reconciliation, but I suppose one could say that this is reconciliation where it matters. Louise said she wanted me to be a witness so that I could tell other people about it all and how reconciliation worked at the personal level. She characterized the sentiments in the people from Jean-Marie's family: those who didn't know what it was all about; those who didn't understand why it was such a big deal; those who were fearful; those who were drunk and those who felt directed by God.

Extract 18 January 2011

I can't remember how it came up, perhaps something on TV about voter registration. The TV news in Kinyarwanda is usually on just before we eat. It often is the catalyst for what we talk about over dinner. We have discussed

maternity leave - Rwandans have excellent provisions - and broadband internet - the government has already taken the decision; the city of Kigali will become an WiFi hotspot later this year - the cable is laid and you see the little yellow posts saying 'fibre-optic cable' everywhere. Louise is very proud of the achievements of the President, Paul Kagame. She thinks he is a man with a great vision for the country. Today I learned that all Rwandans are registered in an electronic system. They can dial a code and up comes their record - voter registration number, ID number and personal details. Louise showed me her record. It's quite scary to think through the consequences, particularly when you put this alongside the aim for every household to have a mobile phone by

2015.

Extract 20 January 2011

I went to visit $B$, who is ... involved in civil society. She said that a big challenge in her role was not saying something which would land her in prison or worse. She is the first person who has talked about the darker side of a reformist government. She explains that one of the priorities of civil society is to get a Freedom of Information Act before Parliament. There is no access to the workings and deliberations of government, people just get presented with the decision. Even the budget is not presented for discussion. I heard yesterday that scholarships were withdrawn from many orphans and with no notice, just an announcement one day last week. Today there was a fiat that prohibits the sale of undergarments and washcloths, to take effect in ten days. This will apparently have a big impact on some women in the market who sell these clothes imported from Uganda and Kenya.

Extract 22 January 2011

Louise is preoccupied by the elections. She explains the system of representation to me and through that I learn about how the local areas are organized, from the 'umugudugu', a grouping of 150 houses, to the akagari which is the smallest administrative/political unit, to the umurenge which 
makes decisions and implements them through its political committee and its community development committee and then to the akarere which has

legislative power and is known in English as a District. The Districts are grouped into Provinces. As I understood it, those elected at the akagari level are the group from which representatives at the umurenge level are elected and so on. So, elections at the grass roots level determine the outcome at the

District level.

\section{Extract 27 January 2011}

To the Gisozi Genocide Memorial on a tourist bus. Overwhelmed by the mass graves and have to leave.

Growing up in post-war Britain, with a father who had spent more than three years as a prisoner of the Japanese, I always believed that I had been brought up to understand toleration and to be tolerant, to recognize the innate humanity of individuals and not condemn them just because they were German or Japanese or were different from us in some other way. My father is not a religious man; he did not take this stance from religious beliefs. If he was influenced, it was by the man who acted as his Commanding Officer ${ }^{1}$ at the beginning of his time as a prisoner of war and whose approach was that the men should forgive - forgive, but not forget.

I wondered whether my father would have had the same reaction if he had been confronted with Japanese people on a daily basis. This tolerance, the one I had grown up with, was an abstract construct. For Louise, tolerance was a lived reality. Processes of reconciliation were part of everyday life. It involved living in a street where some neighbours might have wanted to kill you and others, in acts of courage, might have saved your life. It involved doing business with people who might have killed a friend or relative. It involved having your relatives acknowledge that they had undertaken or supported terrible acts and yet still accepting them. I struggle with my reactions.

Extract 29 January 2011

There was a grenade attack at the bus station about 15 minutes walk away.

Once we know all the girls are safe, Louise tells me that there is no need to worry, they will soon find out who did it - someone will know and they will inform the police. The catchphrase 'If you see something, say something' is a reality here.

Extract 30 January 2011

Yesterday, Melissa and I went to Umuganda, which is a kind of community service. We saw local politics in action. The purpose was not really to cut down the weeds but to get members of the community together, checking off who is there. They had voter registration cards there to hand out too.

Extract 30 January 2011

What a different view of reconciliation! M., our driver on the excursion to the lake, was talking rather coyly about his children. Anita asked him how many he really had and after some hesitation he replied that he had 12 children and that he had had two wives. The first he had loved, she was beautiful, but during the genocide, she had wanted to kill him. She had told lies about him, he said, and he had spent some months in prison. When he was released from

\footnotetext{
${ }^{1}$ As an adult in Australia, I realised the depth of influence of this Australian Commanding Officer, 'Weary' Dunlop.
} 
prison, he went to Tanzania so that she had less chance of succeeding and on his travels, he had met and married another woman. Eventually, he had come back to Kigali with his second family. He thought his first wife still wanted to harm him. He thought the gacaca was dangerous because there was no way of checking if what people said happened really happened like that.

Extract 1 February 2011

Heroes Day, a public holiday. Louise was responsible for organizing the local gathering. She had to give a speech about heroes - and she chose to speak about women who are heroines in their families.

Extract 2 February 2011

The Minster for Women's Affairs hosts a function for the members of the National Women's Council. I see Louise on TV. It's the first time I realized what political influence she must have had. "She says: I've done my best to make sure there are other women who will stand for election. We have to have a strong showing at this local election. Without this, who knows what will happen at the next presidential election."

Extract 4 February 2011 Election day. Quite a different process from our balloting system; voters have to stand behind their candidate. I ask if I can go to see what happens. "No, it wouldn't be right. I know you would be there to learn but people would think you were a journalist and were going to say things about our Rwandan way of doing things. No, we can't have outsiders.”

\section{I-witnessing}

In this paper, I attempt to keep faith with the promise I made to be a witness, but I also seek to go beyond that, to explore my lived experience of cosmopolitanism. I am not a witness of everyday life in the family. I am a witness for a woman who was living the government's policy of unity and reconciliation and at the same time I am my own witness, a woman who was asked to move well beyond the role of stranger or guest that she had expected to play.

In this undertaking, I acknowledge my background as an academic and seek to use scholarly methods to frame this process of witnessing and the exploration of cosmopolitanism. When I formally acknowledged that I would be a witness for Louise, I heard echoes of Denzin and Lincoln's words about the purpose of the 'new ethnography' being “to understand a self or some aspect of a life lived in a cultural context" and express it through a "personal narrative" (2007, p.213). My approach, then, is ethnographic, broadly following Alvesson's approach to self-ethnography (1999). In this context, the exploration of my experiences and learnings should be seen as “confessional” (Van Maanen 1988). This, in part, is a consequence of my decision not to make audio and video recordings of my interactions within the family, but 
only to keep my diary as a traveller might and to take the kind of photos a guest in a family might take. More significantly, it is because I am also a witness for myself, taking a reflexive approach to my experiences and my conceptual understandings (Alvesson 1999).

The notion of being a witness for someone else's life and culture brought to mind Geertz's use of the metaphor of the I-witness, and his assertion that as an ethnographer, "to be a convincing “I-witness” one must, so it seems, first become a convincing “I”' (Geertz 1988, p.79). Golden-Biddle and Locke argue that authenticity is important in claiming authority in ethnography; the reader needs to be assured that the researcher was 'there' (1999, p.373). Even if I succeed in presenting myself as a convincing "I”, I am still left with the task which Clifford describes as representing “otherness”, transforming “unruly experience” into an “authoritative written account” (Clifford 1999, p. 283). For Clifford, ethnography is a "continuous tacking between the "inside" and the "outside" of events: on the one hand grasping the sense of specific occurrences and gestures empathetically, on the other stepping back to situate these meanings in wider contexts” (1999, p. 290). I will seek to go beyond the reflection that this process involves, using the literature to engage reflexively with my own understandings of what it means to be a “witness” to someone else's experiences.

Ethnographic research, with its strong emphasis on interpretation, requires that the positioning of the ethnographer be transparent and that requirement is even more important in auto-ethnography. This "I" was not a researcher who had set out to investigate aspects of the life of a woman in a professional Rwandan family, nor had this "I" established herself as a “professional stranger” in this context (Agar 1980). This "I” has used ethnographic methods in much of her research, in studies of sense-making and information use in everyday decision-making, and in studies of the way young people engage in civil society online and understand community. This "I” has been influenced by Clifford’s approach to writing ethnographies (1999) and Geertz's interpretive approach to the development of theory (1993) has informed much of her work in the past fifteen or more years. Thus, "I" acknowledge that this particular ethnographic inquiry will not be a "relatively simple look, listen and learn procedure but rather as something akin to an intense epistemological trial by fire” (Van Maanen quoted in Alvesson 1999, p. 7). It seems that the circumstances for this "I” were close to those described by Alvesson (1999 p.13), an auto-ethnography with an 'emergent spontaneous approach’ carried out 'when something revealing happens' (Alvesson 1999, p.13). 
Having established my credentials as a researcher, I also need to establish my credentials for having “been there”. I lived in Louise’s house in Kigali for nearly six weeks, spending two or three hours every day talking with her, laughing and joking, exploring our lives of women of a certain age, with daughters who are now young women. I speak only a few words of Kinyarwanda, the local language, enough for everyday pleasantries, but not enough to hold a conversation. However, I speak French very well because of my university education which was conducted in French and because I lived and worked in France and this is the language Louise and I used all of the time. French was the colonial language of Rwanda and until the end of 2009 the language of high school education. Most educated Rwandans of my age are highly literate in French, having received their university or professional education in French.

My ability to speak French, understanding its grammatical and social nuances, and to take part in conversations on topics related to issues of contemporary concern (on the basis of my reading and my interactions with Burundians and Rwandans living in Australia) seemed important in the process of narrowing the distance between Louise and myself. Her willingness to open topics of conversation in such a way that I could take part also contributed to narrowing the distance. Another factor may have derived from the influences of my undergraduate education, which have led me to strive to understand 'the Other' in cultural terms; as my cultural interpreter in Burundi in 2009 put it, "to quietly observe and then take part”.

\section{Being a Witness in Rwanda}

The eye-witness occupies an important place in contemporary Rwandan society. 'Les temoignages' are the testimonies of those affected by the genocide in 1994 . They are stories told in the gacaca, (the traditional cultural communal law courts re-established after the genocide as a means to bring justice and closure at the local level and abolished in the first half of 2011), stories told to the media, stories repeated in families and stories documented in the many memorials to the victims of the genocide, such as the Gisozi Genocide Memorial http://www.kigalimemorialcentre.org/. They are stories told today, by genocide survivors and orphans such as Joseph, a young activist I was introduced to.

Louise's story, the story of a genocide survivor, is at one level, a story repeated thousands of times over. It is story of local terror and local bravery, of uncertain survival and humiliating 
death, of displacement, loss, return and re-commencement. It is also a story of how members of a family of mixed background were reconciled. It was the process of return and reconciliation, which she revealed to me little by little, that Louise wanted me to witness.

This is also the story of an Australian woman seeking to understand the re-building of civil society in Rwanda at the local level and to come to terms with being seen as a threat to this process; and to be witness to her own struggles with the challenges to her understandings and experiences of being a good guest, of cosmopolitanism and of the implications of reconciliation.

In an exploration of these processes of witnessing, I will attempt to make sense of my experiences through a consideration of conceptual literature but importantly I will go beyond these experiences to rethink some aspects of the literature. I will explore conceptions of the guest, the stranger and the cosmopolitan. I will discuss conceptions of cosmopolitanism and in that context consider the concept of reconciliation. Thus, as I reflect on what it means to be a witness to events in someone else's life and to be a witness of my own involvement in this process, I recognize that I need to consider the concepts of the guest, the stranger and the cosmopolite or cosmopolitan to try to understand my own position. In conceptualizing reconciliation; it is not enough to acknowledge that I cannot share in Louise's sense of reconciliation because of my own lack of experience with lived realities. Rather, it is important to reflect on the concept itself and re-assess it in the light of experience and a considered understanding of related concepts.

\section{Exploring Cosmopolitanism}

\section{The Guest, the Stranger and the Cosmopolite}

I went to stay in Louise's house as a guest and made promises to her in my attempts to be a good guest. However, the statement that I went as a guest is misleading. We did not know each other and she did not invite me. Rather, through a chain of friendships ${ }^{2}$, she agreed to take me in. Thus, I began my relationship with her in an ambiguous position, rather as a 'visitor' than as a 'guest'. However, this did not mean that she accepted me with unconditional hospitality, not needing to know my name or anything about me. I did have

\footnotetext{
${ }^{2}$ A close friend is a well-networked Burundian refugee who made a request to Rwandan acquaintances, currently in Australia for training or as students, to find a family who might offer me accommodation. One of these contacted her friend in Kigali, who discussed it with her parents who agreed without hesitation to take me into their house for nearly six weeks.
} 
email exchanges and a telephone conversation with her oldest daughter and she did ask me questions about myself when I arrived in her house. Derrida, in his discussion of Kant's piece on Cosmopolitan Right and Hospitality, noted that unconditional hospitality was impossible to achieve. It is impossible to open one's home to other people without this exchange and without establishing boundaries of behaviour (2000). Westmoreland emphasized that hospitality is almost always bounded in that the guest is asked to accept a set of conditions (Westmoreland 2008, p.2). And so it was in Louise's house - she set rules which she asked me to accept as promises to her - not to get up before an agreed time, not to use the shower but only to use the water that was brought to me for washing and to eat two slices of bread for breakfast.

Derrida is concerned with the ambiguous nature of the relationship between the guest and the host. In French, the ambiguity is immediate, because the words for guest and host are the same. However, even without this linguistic ambiguity, there is ambiguity in the relationship, because becoming a good host may involve giving the guest power over some aspect of the relationship. Thus, Louise reasoned that as someone with no exposure to malaria I needed to be protected from mosquitoes and she had screens fitted at all of the windows in the house. Thus she, the host, subordinated herself to me, the guest, in the very act of being a good host.

The notion of hospitality and the relationship between guest and host are problematic in a number of ways. On the one hand, hospitality is about welcoming a person whom you may not know, but on the other hand, it is about recognition. Derrida notes that it may involve a constant negotiation and re-negotiation of the relationship between guest and host. This relationship is about establishing a sense of proximity, but at the same time, maintaining a distance. Towards the end of my stay, Louise was introducing me to women in the neighbourhood as her cousin and joking that the differences in our hair and the colour of our skin did not prevent us being closely related. However, linguistically we seemed to deliberately maintain a distance; although from time to time we used the familiar form of address in French (tutoyer), we seemed unable to sustain its use. The use of the formal 'vous' enabled us both to keep a distance.

The unbounded, cosmopolitan hospitality that Kant proposed and Derrida (2000) and Levinas (1979) elaborated was impossible. Louise set rules for me to live in harmony with her and her family. Linguistically, we treated each other as equals, but also with formality and reserve. 
Thus, both host and guest imposed limits on the relationship of hospitality. When Louise asked me to promise her something, I agreed as a good guest. Her request pointed up the structural imbalances involved in being a guest as the request to be her witness was not directed at me as a guest, but rather at me as other. The role of witness changed our relationship as it was a constant reminder that I would be leaving her house not just to return to my own house, but to return to my community and tell my family, friends and colleagues about her experiences during the genocide and my understanding of them.

I thought that I had gone to Kigali as a "cosmopolite”, , a role I was introduced to many years ago as an undergraduate, which draws on my facility with colonial languages (English, French and Spanish), my wide reading and a broad circle of acquaintances to give me a solid introduction into other communities and which I had accepted uncritically. If the role of “cosmopolite” was not effective, I thought could draw on my experiences of the broader role of the ethnographer I had developed as an academic. However, my experiences and in particular the demands that Louise made of me showed that the "I" that I had constructed for the I-witness was partial, inadequate and lacking in authenticity. The "I” has to be capable of establishing strong links of commonality to be the witness to reconciliation but at the same time to be different enough to be recognized as an outsider in the political context and therefore potentially as a threat.

Ethnographers are represented both as strangers and as cosmopolites in the literature of ethnography, a conceptual position I had been comfortable with. Agar uses the phrase "professional stranger” to label the ethnographer, someone who "collaborates with another person ... to create a social relationship within which an exchange of information occurs" (1980, p.1). This person has to be able to balance involvement with detachment, exploring the difficulties of stepping into and out of a society (1980, p.50-51) and to become part of a society, they need help and assistance, whether through a letter of introduction or through the intervention of a "professional stranger-handler", someone who can "find out what the outsider is after and quickly improvise some information that satisfies him without representing anything potentially harmful to the group” (1980, p. 85). The uncritical

\footnotetext{
${ }^{3}$ Geertz (1988, p.79) uses the tem to refer to Malinowski, an anthropologist through whose practice he explores the concept of 'I-witnessing'. According to Geertz, the cosmopolite is the 'figure of such enlarged capacities for adaptability and fellow feeling, for insinuating himself [sic] into practically any situation, as to be able to see as [others] see, think as [others] think, speak as [others] speak and on occasion, even feel as they feel and believe as they believe".
} 
acceptance of these conceptual positions does not advance an understanding of what it means to be both a witness and a threat.

Therefore, I attempt to understand more critically what it means to be a stranger from a sociological perspective. The classic conceptualization of the stranger comes from the work of Simmel, the cultural outsider, who has become "the potential wanderer" (Simmel 1950, p. 1 of 3), someone who is "fundamentally mobile", who comes into contact with many people, but who is not connected to any of them by "kinship, locality and occupation” and who has made a commitment to "stay tomorrow" (Simmel 1950, p. 1 of 3). Simmel considers being a stranger a "specific form of interaction", which is based on that mixture of "nearness and distance, indifference and involvement” which leads to objectivity. This objectivity is an important characteristic as it may lead others to confide stories they would not tell to those closer to them. The in-between stranger is linked to those on the inside by a recognition of common features of a "national, social, occupational, or generally human, nature" but at the same time separated from them because "similarity, harmony and nearness are accompanied by the feeling that they are not really the unique property of this particular relationship” (1950, p.3 of 3). I am drawn to the notion that the stranger is not a person but a type of interaction, and the concepts of nearness and distance, indifference and involvement seem to have relevance. However, at the same time, I recognize that Simmel's view of the form of interaction which constitutes the stranger is dated, conceived as it was nearly a century ago. Bauman offers a much more recent perspective. He suggests that from a modernist perspective, strangers are those who do not fit the idea of order in a society. They are not those in whom I might confide, they are rather "hateful and feared” (Bauman 1995, p.10). From a contemporary, postmodern perspective, strangers are essential to societies as a mark of difference, and there is "an almost universal agreement that difference is not merely unavoidable, but good, precious and in need of protection and cultivation” (1995, p.13). Until such time as people have adequate resources for building their own identity and for developing strong notions of citizenship, this sense of distasteful distance, of needing the hateful for creating one's own sense of self, will persist (1995, p.16).

In the context of my wish to observe Rwanda's local election process, I found myself albeit briefly, in the position of being the outsider, something different, the stranger, to be feared, as Bauman describes. This was something of a shock. To be feared because I was interested in how the democratic process worked or because I came from a democratic country with a free 
press was something I had not expected in my uncritical view of myself as the cosmopolite. I had not considered that others might see me as the kind of threat to which B. had alluded (diary extract 20 January 2011), someone who might make critical comments about the processes of government or about the policies and decisions of the President and who might therefore upset the societal order which the Rwandan government has worked so hard to enforce.

This was the first of those disjuncts in my understanding of cosmopolitanism. I was forced to reconsider my uncritical understanding of the concept of the 'cosmopolite', and consider cosmopolitanism as a concept concerned with power as well as with the moral.

\section{Reconciliation}

Appiah recognises the notions of universal concern and respect for difference, but acknowledges that there will be disagreement and conflict from time to time. Like Arendt ${ }^{4}$, he uses the notion of the conversation as a metaphor to present an understanding of cosmopolitanism, asserting that "Cosmopolitans suppose that all cultures have enough overlap in their vocabulary of values to begin a conversation.” (2006, p.57) although this “[c]onversation doesn't have to lead to consensus about anything, especially not values; it’s enough that it helps people get used to one another” (2006, p.85).

The notion of the conversation with the stranger is a powerful one for beginning a process of understanding as Appiah and Arendt propose. My conversation with M. (diary extract 30 January 2011) was just such a conversation - I was never going to be more than a stranger to M. and he to me, as it was unlikely that I would meet him again, given that he had been hired to drive a group of foreigners of whom I was one on an excursion. In Bauman's terms, M. would be a stranger to me too but not only because of the differences in skin colour and status. My limited understanding of the interactions in post-genocide Rwandan society suggested that people like him who had been in jail because of their actions during the genocide were the focus of policies and programs of state-based reconciliation. His story showed that he had not achieved personal reconciliation with his first wife and his family,

\footnotetext{
${ }^{4}$ Arendt proposed the notion of a 'theoretical conversation' where the outcome is a 'potential agreement with others" and where an enlarged way of thinking ... cannot function in strict isolation or solitude; it needs the presence of others 'in whose place' it must think, whose perspective it must take into consideration, and without whom it never has the opportunity to operate at all” (1961, pp.220-1, as cited by Benhabib, 1992, pp. 9-10).
} 
friends and neighbours from the time of the genocide. I found myself wondering about his actions in the genocide, seeing him potentially as someone to be feared, thinking about how others who knew his story would regard him.

I had been perplexed by the possibilities of personal reconciliation for some time. In Burundi where I had spent three weeks with a family in December 2009, I had met Tutsis of my generation whose extended families had been killed in the massacres which took place there and who felt tremendous bitterness towards Hutus at large. At the time, Burundians were preparing for the election of their president, and one man said: "How can I vote for them? I know that [the Hutu President] has done a lot for the reconstruction of the country. But they killed my family, my mother, my father, all my brothers and sisters except the sister who was with me, their children too. I can’t forget that.”

Louise was quite clear that reconciliation for her was a private matter (Kohen 2011). Her belief that her Catholic God was encouraging her to take the step towards reconciliation and to heal the rift with her husband's family was a strong motivating factor. Another strong motivating factor was the need to preserve the possibility of familial relationships in the future, to allow the next generation the possibility of living in harmony. That it had taken sixteen years to come to this point shows how significant an action this was. Her categorization of the sentiments of those members of her husband's family who came to the lunch and were part of the process indicates that even those engaged in the process of reconciliation acknowledge that others in that process do not share the same objectives (diary extract 16 January 2011). Reconciliation might only be noticed by the individual, although others participate in the activities.

This categorization can begin to indicate important elements in the process of reconciliation. Information about what happened would have been important for "those who did not know what it was all about”. Being confronted with the so-called victim, hearing the lamentations and being told of the consequences of the actions might have been important for "those who didn’t understand why it was such a big deal”. Believing that God could bring peace through directing the behaviour of believers would be a strong force for many Catholics. Learning that there were no detrimental consequences, no desire for revenge, no intention to bring criminal charges might have gone some way to alleviate the stresses of "those who were 
fearful”. The acknowledgement that there were also "those who were drunk" might indicate that there were also those who were not ready to confront the reconciliation process.

Personal reconciliation, then, may not be concerned with notions of "forgiving the unforgiveable” as Derrida indicates (2001). In Louise’s case, reconciliation does not seem to match Levinas's notion of “giving the past a new meaning” by re-narrating it (1979, p.282). Indeed, she was quite clear that it was not right to accept intolerable practices. Thus, it may come closer to Arendt's idea that forgiveness comprises two parts, the act and the agent, where it may be possible to "forgive somebody without forgiving anything" 5 .

Louise was very clear that I was to be her witness in this process of reconciliation, and thus it was clear that it was not only a personal matter. Rather, she wanted me to be able to express a view and explain to that world of which I am a part and she is not. In terms of her categorization, she had ensured that I was well informed and that I understood why the process of personal reconciliation was important to her. She knew that I did not have a faith which would direct me to take certain actions.

I belonged by my own admission to the group of those who were fearful. What was I fearful of? Was it fear that prevented me from being entirely engaged in the process of reconciliation? And what are the consequences of my answers for a conceptualization of the cosmopolitan? I was fearful of being a witness to what I had conceived as a private, family, matter. At the time, I protested that I felt “de trop”, superfluous, in the way. This was not a matter that should concern me. It was about the future of relationships of which I was not a part. I was afraid too that I would have to move beyond my abstract notion of tolerance and come to something other than an intellectualized position on the Rwandan genocide and the post-genocide process of unity and reconciliation. This did not fit with the role of cosmopolitan that I had willingly taken on. Further, it challenged the values of openness and tolerance by which I believed I had lived, because I had no way of understanding the terrible things which had happened. I felt inadequate and I resisted, in spite of Louise's encouragement that it was important for her that I did consider myself part of this process of reconciliation.

\footnotetext{
${ }^{5}$ Arendt noted that she was not concerned with "evil”, and that may negate the comparison.
} 
Here was a second significant disjunct in my understanding of cosmopolitanism. I had been able to accept that several concepts of cosmopolitanism might co-exist, that the moral cosmopolitanism that I favoured was not negated by some other conceptualisation. In practice, I was faced with an "incommensurability of perspectives” which actually demonstrated ignorance (Beck \& Sznaider 2010, p.399). Delanty’s post-universalist cosmopolitanism gives me a way to begin to re-think this position. He suggests that cosmopolitanism should be seen through "the tension between the global and the local on the one side and on the other the universal and the particular" and that a third dimension of cosmopolitanism, a cultural dimension, is concerned with openness in communication (2006, p.35) He goes on to indicate that to the extent that cosmopolitanism can be seen in everyday interactions, a cosmopolitan imagination emerges which gives the possibility of transforming both Self and Other (2006, p.37).

\section{Cosmopolitan Curiosity}

The classic conceptualization of the cosmopolitan argues that an individual's relationship with humanity at large is more important than relationships with others from the same state or nation. 'Citizen of the world', a phrase whose meaning derives from the word cosmopolitan, has become part of a popular contemporary Western vocabulary and a phrase which I had been happy to believe could be applied to me. However, my shock in understanding that there were circumstances where it could not apply showed that a more considered approach to the meaning of the cosmopolitan is required.

Held's cosmopolitanism "recognizes each person as an autonomous moral agent entitled to equal dignity and consideration” (Held 2010, p.15). As an ideal abstract position this appeals to me, but I see it unworkable in the practice of everyday life. A more nuanced approach may come from the notions of thick cosmopolitanism and thin cosmopolitanism which may lead to conceptualisations that are closer to experiences of lived realities, with thick cosmopolitanism existing when all moral claims are justified by showing that they give equal weight to the claims of all and thin cosmopolitanism existing when certain treatments are afforded to all regardless of relationships, but "other kinds of treatment [are given] only to those to whom we are related in certain ways...”(Held 2010, p. 78).

For Appiah, cosmopolitanism can arise from a cross-cultural conversation whose starting point does not have to be something universal, it just needs to be something the people in the 
conversation have in common. When we enter into such a conversation with a stranger, this is not a stranger in the abstract but a particular stranger, with whom we may be able to establish a bond of shared identity. The conversation then can become the starting point for understanding things which are not shared. A mark of the cosmopolitan is that they "enjoy" discovering differences and use this "cosmopolitan curiosity” to explore differences and learn from others, or to "simply be intrigued by alternative ways of thinking, feeling and acting" (2006, p.97). They also have the intelligence to look beyond the immediate differences or problem to try to take a broader perspective, seeing that features of their own context may be related to the creation of difference or to the problems of others (2006, p.168).

Beck insists on a break with what he considers the philosophical approach that Held takes. Rather, he envisages a cosmopolitanism which equates with praxis and is closer to a political construct. This cosmopolitanism arises from concrete social realities and recognises difference (Beck \& Sznaider 2010, p.386). Thus it causes us to rethink nationalism and globalism, as well as the traditional and the modern. Cosmopolitanism thus is a transformative concept, as it also includes the individual and the local alongside the global. For Beck, the process of "cosmopolitanisation" should be the focus of concern. In his words, this means "the erosion of distinct boundaries dividing markets, states, civilizations, cultures, and not least of all the lifeworlds of different peoples" and it is important that this process takes place in the everyday lives of individuals (Beck 2007).

Appiah's version of cosmopolitanism seems to offer me a way to conceptualise the cosmopolitan because of its match with my experience. The characteristics of conversations with Louise, the focus of my exploration of what it means to be a witness, are thrown into relief by an almost casual conversation over lunch with $\mathrm{M}$, the driver on an excursion, as discussed above. One key characteristic of my conversations with Louise has been the existence of a "cosmopolitan curiosity" where we have both sought to go beyond a simple bond of shared identity. But this characteristic was missing from my conversation with $\mathrm{M}$.

From a personal perspective, the unwillingness to take part in the process of reconciliation also demonstrated that, at this significant time, as in my conversation with M., I did not show that cosmopolitan curiosity which had marked other conversations Louise and I had had. Because the experiences were so confronting, so far beyond my experience and imagination, at the time I chose not to enjoy exploring the differences between Louise's experiences and 
my own. Louise was able to demonstrate what Beck refers to as cosmopolitan tolerance. He defines that as an active sentiment, involving "opening oneself up to the world of the Other, perceiving difference as an enrichment, regarding and treating the Other as fundamentally equal”. I had found that cosmopolitan tolerance beyond me as well as cosmopolitan curiosity. Here then was a third disjunct and one which was significant as its very existence seemed to withhold the possibility of a conceptualised cosmopolitanism existing in everyday experience.

\section{Conclusion}

Beck's distinction between the philosophical, moral position of Held and others on cosmopolitanism, and his own more pragmatic, political position enables me to move beyond the sense of being a failed cosmopolitan, trapped in the position of 'Other' (Beck 2009, pp.56) and to elaborate three disjuncts in using the concept of cosmopolitanism to explore experiences in everyday life. These disjuncts were:

- the realisation that a moral cosmopolitanism and a political cosmopolitanism can not only co-exist but that, in different interactions between the same individuals, the balance between them can shift, thus changing the nature of the relationships between those individuals;

- the recognition that at times, the attempt to acknowledge several perspectives on cosmopolitanism can bring one to confront an incommensurability of perspectives which reveals a long-held ignorance;

- the acknowledgement that the transformative aspect of cosmopolitanism, which arises through conversations, communications and curiosity about the world beyond simple bonds of shared identity, can be extremely difficult to sustain especially when the balance between moral and political cosmopolitanisms is constantly shifting.

The positions I took in my relationship with Louise may not always have been those of the cosmopolitan I had aspired to. Yet, on reflection, there were many factors which indicated structural imbalances in that relationship and which therefore made cosmopolitan curiosity and the transformative aspect of cosmopolitanism a practical impossibility. The relationship 
of guest and host is not one of equals and although, with good will, boundaries can be flexible, the host will always have power over the guest and her behaviour. I was the stranger, literally the foreigner, the outsider ${ }^{6}$. I was Simmel's stranger, the one in a position to take an objective perspective on what I heard and saw, the one frequently asked to offer an opinion comparing some aspect of Rwandan life to life in Australia. I was also from time to time Bauman's stranger, someone to be feared because I was thought to be in a position where I could expose local practices or government policies and potentially comment unfavourably on them to a world outside of Rwanda, outside the reach of social and political powers. Beyond that, Louise and I each represented the Other. She was Other because she had life experiences which set her apart from me. Although she introduced me as her cousin ${ }^{7}$ to the women in the market cooperative she supports, they saw me only as Other, because of where we each live and our life experiences, through the colour of our skin, through our communication, mediated as it was through French which we both speak fluently but which is a learned language for both of us and not a language which the women in the market cooperative were comfortable with.

In this paper, I have kept faith with the promise I made to be a witness, a witness for a woman who was living the government's policy of unity and reconciliation and a witness of my own experiences. In this process of witnessing, I have explored concepts of the cosmopolitan and the stranger, of cosmopolitanism and reconciliation. I have identified three significant disjuncts which have affected my capacity to be an 'authentic' witness, in ethnographic terms. At the same time, from a conceptual perspective, there are structural imbalances which made cosmopolitan curiosity, a potential basis for a future-oriented relationship based on complete equality, extremely difficult. This reflexive exploration of these experiences in Rwanda has shown that cosmopolitanism is much more difficult to sustain as a lived reality than it is as an abstraction.

\footnotetext{
${ }^{6}$ When Rwandans speak of people not in Rwanda, they refer to them, in English, as being “outside”.

${ }^{7}$ Louise joked that the differences in our hair and the colour of our skin did not prevent us being closely related, as cousins. Naming me her cousin drew attention to what might bring us to seem related much more forcefully than if she had referred to me as her 'sister'. Her 'sister could have been her 'sister in Christ' (which given my views on religion was not possible) or it could have been her feminist sister from another National Women’s Council.
} 


\section{Bibliography}

Agar, M. 1980, The Professional Stranger: An Informal Introduction to Ethnography, Academic Press, New York.

Alvesson, M. 1999, Methodology for close up studies - struggling with closeness and

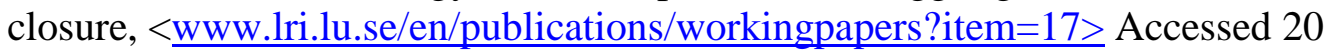
September 2005.

Appiah, K.A, 2006, Cosmopolitanism: Ethics in a World of Strangers, W.W. Norton, New York

Bauman, Z. 1995, 'Making and unmaking of strangers', Thesis Eleven, vol. 43, pp.1-16

Beck U. 2007, 'A new cosmopolitanism is in the air', www.signandsight.com/service/1603.html Accessed 2 May 2011.

Beck, U. 2009, 'Critical theory of world risk society: a cosmopolitan vision', Constellations, vol.16, no.1, pp.1-22.

Beck, U. and Sznaider, N. 2010, 'Unpacking cosmopolitanism for the social sciences: a research agenda’, British Journal of Sociology, vol.61, Supplement s1, pp. 381-403.

Benhabib, S. 1992, Situating the Self: Gender, Community and Postmodernism in Contemporary Ethics, Routledge, London.

Clifford, J. 1999, 'On ethnographic authority', in Bryman, A. \& Burgess, R. (eds.), Qualitative Research, vol. III, Sage, London, pp. 281-310.

Delanty, Gerhard 2006, 'The cosmopolitan imagination: critical cosmopolitanism and social theory', The British Journal of Sociology, vol. 57, no. 1 pp. 25-47.

Denzin, N. and Lincoln, Y, 2007, Collecting and interpreting qualitative materials, Sage, New York.

Derrida, J. 2000, 'Hostipiality’, Angelaki, vol.5, no.3, pp. 3-18

Derrida, J. 2001, On Cosmopolitanism and Forgiveness (Thinking in Action), Routledge, London.

Geertz, C. 1993, 'Thick description: Toward an interpretive theory of culture', in The Interpretation of Cultures; Selected Essays, Fontana, London, pp. 3-30.

Geertz, C. 1988, Works and Lives: The Anthropologist as Author, Stanford University Press, Stanford, Ca.

Golden-Biddle, K. \& Locke, K. 1999, 'Appealing work: An investigation of how ethnographic texts convince', in Bryman, A. \& Burgess, R. (eds.), Qualitative Research, vol. III, Sage, London, pp. 369-396.

Held, D. 2010, Cosmopolitanism; Ideals and Realities, Polity, Cambridge.

Kohen, A., Zancheli, M. and Drake, L. 2011, 'Personal and political reconciliation in postgenocide Rwanda', Social Justice Research, vol.24, no.1, pp. 85-106.

Levinas, E. 1979, Totality and infinity: an essay on exteriority, M. Nijhoff, The Hague.

Simmel, G. 1950, 'The Stranger' in Wolff, K.H. (ed.) The Sociology of Georg Simmel, The Free Press, New York,

Van Maanen, J. 1988, Tales of the Field, University of Chicago Press, Chicago.

Westmoreland, M. 2008 'Interruptions: Derrida and Hospitality', Kritike vol.2, no.1, pp.1-10. http://www.kritike.org/journal/issue_3/westmoreland_june2008.pdf Accessed on 3 May 2011. 